Pre-print del artículo enviado a "The World Economy"

Tras los cambios realizados a sugerencia de los evaluadores anónimos, el artículo fue publicado como: Córcoles D., Díaz-Mora, C. y Gandoy, R. (2015): "Export Survival in Global Value Chains", The World Economy, vol. 38, Issue 10, 1526-1554. https://doi.org/10.1111/twec.12249

\title{
Export Survival in Global Value Chains
}

\author{
David Córcoles (David.corcoles@uclm.es) \\ Carmen Díaz-Mora`^(Carmen.diazmora@uclm.es) \\ Rosario Gandoy (Rosario.gandoy@uclm.es) \\ University of Castilla-La Mancha (Spain)
}

\begin{abstract}
:
This paper focuses on the survival capacity of the trade flows in international production networks. Firstly, we emphasize that these trade relationships are longer-lived than other trade flows. Secondly, we try to delimit the factors that explain this using time-discrete duration models which control for the existence of unobservable heterogeneity. We find that variables such as initial value of the trade flow, geographic and product diversification, institutional quality, geographic, linguistic and economic proximity and membership in a regional integration agreement play an important role for stability of global production systems. Our results highlight that the high sunk entry costs and the need for trust and reliability in global value chains are factors dissuading radical alterations in the network configuration.
\end{abstract}

JEL codes: F10, F14, C41.

Key words: International Production Networks, Export Survival, Time-Discrete Duration Models.

\footnotetext{
A Corresponding author. Department of International Economics, Faculty of Juridical and Social Sciences, University of Castilla-La Mancha, Cobertizo de San Pedro Mártir, 45071, Toledo, Spain. Carmen.DiazMora@uclm.es, Phone+34925268878, Fax +34925268878.
} 


\section{Introduction.}

In a context of low demand, stagnation in economic activity, and high indebtedness in most of the advanced economies, export growth plays a key role in the economic policy goals. An important factor in explaining long-run differences in export performance is the duration of trade relationships. However, this topic had hardly been explored until the seminal work by Besedes and Prusa (2006a). These authors called attention to the short-lived trade flows. Since then, a broad set of new studies confirm the low rates of survival of new trade flows for different economies and periods and attempt to delimit their causes. ${ }^{1}$

The present paper belongs to this line of research. We aim to investigate the determining factors in the stability of a specific type of trade, namely the exports linked to global production networks (GPN). We expect that trade involved in value chains will be more stable than others. The existence of sunk costs and the required trust and reliability among trade partners involved in international production networks could be factors dissuading radical alterations in the network configuration. That is, once a production network has been established, certain factors could foster the continuity of the ties already established. Some of these factors would be the search of other new appropriate partners in foreign markets; to make capital investments which sometimes require long, costly processes given the lack of knowledge of all sorts of local regulations; to formalise new, incomplete contracts; or to once again incur the costs associated with workforce training.

Empirical literature supporting this stability of trade associated with GPN is extremely scarce and focused on East Asian countries (Obashi, 2010a). Our study contributes to the existing literature by providing a further step to delimit the factors that foster the greater stability of production networks; specifically by proposing a broad set of variables to capture the impact of sunk entry costs, trust and reliability requirements on export duration. Moreover, the estimates are performed using time-discrete duration models that control for the existence of unobservable heterogeneity and deal with some of the disadvantages of Cox's proportional hazard model, according to the most recent studies (Hess and Persson, 2011a).

Our interest in the determinants of the stability of production networks reflects two motives. The first is that the rising presence of exchanges linked to GPN in world trade leads them to exert a major influence on the aggregate behaviour of exports.

The second motive is related to the geographic reorganization of global value chains. Trade liberalisation and the increasing role of China and other emerging countries in world trade have encouraged a reconfiguration of the value chains in order to improve productive efficiency and business competitiveness. In this context, it seems worthwhile to inquire into the fundamental factors that ensure survival in GPN, especially for middle-income economies which could more easily be displaced from the networks by the new competitors.

\footnotetext{
${ }^{1}$ The brief duration of trade flows has been confirmed for the United States (Besedes and Prusa, 2006a), Germany (Nitsch, 2009), the EU (Hess and Persson, 2010), Latin America (Besedes and Blyde, 2010), countries at different stages of development (Brenton et al., 2010; Fugazza and Molina 2011; Besedes and Prusa, 2011) and intra-zone trade in East Asia (Obashi, 2010a).
} 
The study focuses on the Spanish economy in the period 1996-2010. This country is an interesting case for studying the determinants of production networks stability because it has managed to maintain its participation in world $\mathrm{P} \& \mathrm{C}$ exports unlike other advanced economies (Blázquez et al., 2012) ${ }^{2}$. Moreover, Spain shares with New Member States some the characteristics that favoured its integration in European networks and that now stimulate the reorganization to the East in the enlarged EU.

The paper is organised as follows. After this introduction, the second section describes the data set and provides descriptive statistics on duration of exports linked to GPN. Section 3 explores the determinants of export survival to be used as explanatory variables in the empirical model. Section 4 presents and discusses the econometric results, stressing the differences between exports linked to GPN and the remaining exports. Section 5 contains the final considerations.

\section{Data and Descriptive Analysis.}

Following a recent line of research (Yeats, 2001; Kaminski and Ng, 2005), to capture trade linked to cross-border production systems we use P\&C transactions taking into account that, due to their intermediate nature, these are mainly destined for further processing or assembly abroad. For that reason, one of the consequences of GPNs is the increasing P\&C trade. The main shortcoming of this proxy is that we do not consider the last phase of the manufacturing process, that is, the assembly phase, because it is not possible to distinguish assembly from full manufacturing and both of them are registered as final goods exports.

Another shortcoming of this proxy is that trade classifications only consider $\mathrm{P} \& \mathrm{C}$ exchanges for Machinery and Transportation Equipment, which justifies why these branches are the target of our research. Specifically, we use trade data at the 6-digit level of the Harmonised System (HS) for chapters 84-92 (around 40\% world trade), which entails 1,172 headings, 727 of which are final goods and the remainder are P\&C (Kimura and Obashi, 2010). The statistical information comes from the United Nations Commodity Trade Statistics Database (COMTRADE) and the study period is $1996-2010 .{ }^{3}$ We have established a minimum trade threshold of $\$ 1,000$, a common practice in the literature which aims to eliminate from the examination of survival any flows which may distort the results because of their limited size and high volatility. To perform the analysis, we examine the exports of each product to 90 destination countries, representing about 98 percent of Spanish trade in Machinery and Transportation Equipment. Tables A.1 and A.2 in the appendix lists the products and countries, respectively, included in the sample.

\footnotetext{
${ }^{2}$ Besedes and Prusa (2011) point out Spain as a good comparison country, due to its strong growth of aggregate exports and of the number of trade relationships, in their counterfactual exercise to calculate export performance for different economic areas.

3 The two revisions of the HS classification, in 2002 and in 2007, require a process of homogenisation to be performed due to the elimination of certain headings or their reclassification in other codes and the appearance of new ones. In the former case, following Brenton et al. (2010), we choose to remove them from the sample because of their scant importance ( $2 \%$ of the trade value) and because we understand that their deletion from the latest classification reflects a gradual loss in their trade value. The remaining cases pose no difficulty since the latest HS indicates in which headings in the previous classifications they should be placed.
} 
To examine duration of trade linked to cross-border production systems, we use annual data for each product-market pair to create spells, referring to each continuous period of exporting activity by product and destination country. The length of these spells is the number of years in which the export flow of each item to a given destination remains active with no interruptions. The more times the trade flow is interrupted and then later restored, the greater the number of spells and the lower their average duration.

Our basic statistics on the duration and number of spells reveal two facts. The first is the short duration of exports (3.7 years on average), with relationships that last two years being the most common ones. This result is in line with previous studies. The second is the longer length of exports linked to GPN (4.2 years on average compared to 3.4 for final goods), a feature which had already been noted for intra-zone trade in East Asia (Obashi, 2010a).

$\mathrm{P} \& \mathrm{C}$ exhibiting higher export survival rate than final goods may be found in different geographic destinations. Graph 1 shows how the cloud of points that results from plotting the target countries of the exports according to the average duration of the spells in P\&C and in final goods is clearly above the bisector. This reveals the higher survival of flows associated with GPN compared to final goods in virtually all the partner countries. We emphasize the positive relationship between the duration of exports and the greater relative stability of the exports of $\mathrm{P} \& \mathrm{C}$. Thus, the more long-lasting the exporting ties with a country, the greater the differences between the length of exporting spells for $\mathrm{P} \& \mathrm{C}$ and for final goods. This is the case of trade flows with the more veteran members of the EU-15 (especially with the main Spanish partners: France, Portugal and Germany), revealing a heavy and stable integration in GPN at European level. This leads to consider that being part of a regional integration agreement like the EU may encourage longer-lived trade relationships in P\&C. This hypothesis will be checked in the econometric estimates of the determinants of survival.

Graph 1. Length of export spells at product-market level for P\&C and Final Goods (mean).

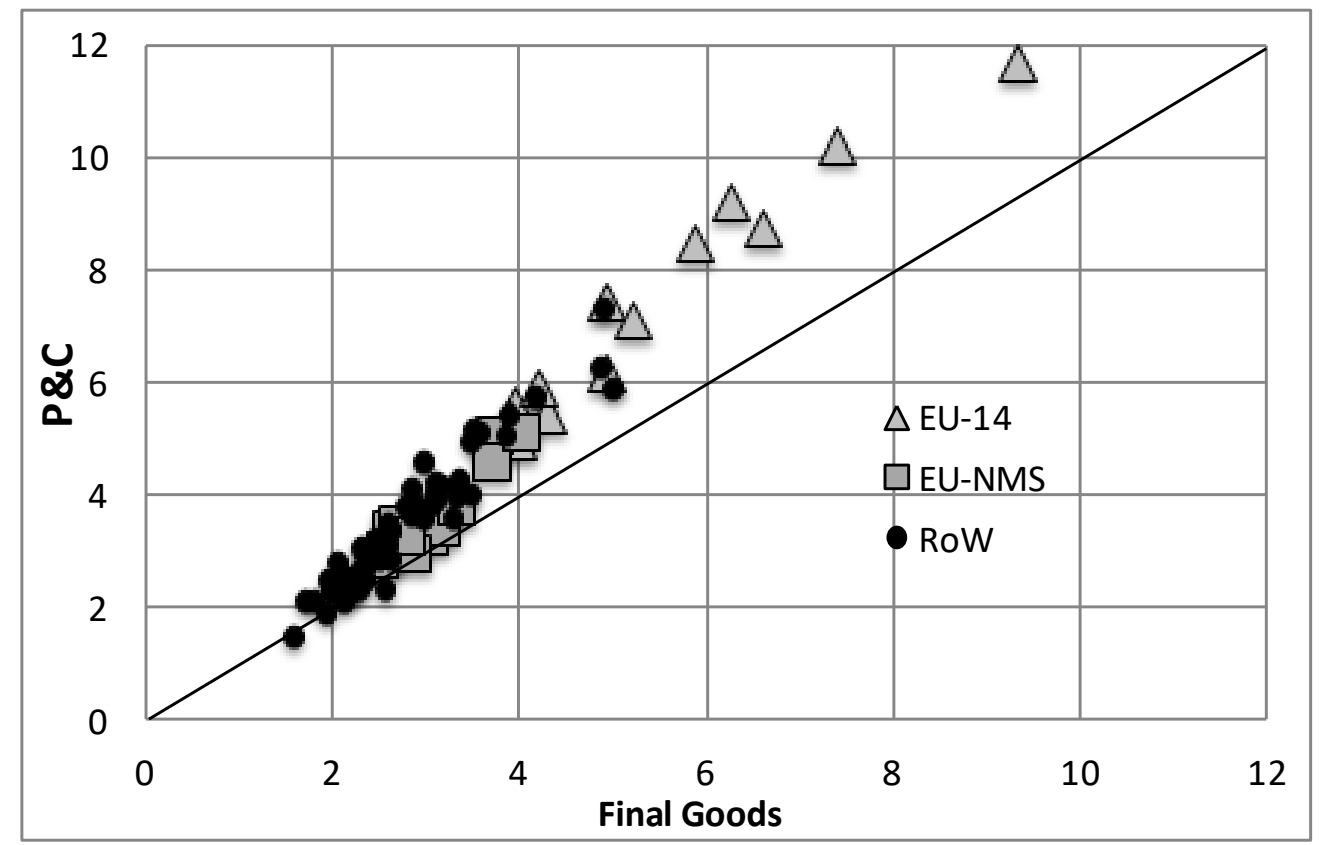

Source: Own elaborations based on UN-COMTRADE data. 
Next, we study the temporal pattern of the survival of exports using non-parametric estimates of the survival function, specifically the Kaplan-Meier method (1958). The purpose is to analyse the probability of ceasing to export at moment $t$, conditioned upon having exported at least $t$ periods. This conditional probability is called the "exit rate" and in constant terms the risk or "hazard" function, and it depends on the duration inasmuch as its value changes with $t$; thus, a negative dependency between $t$ and the exit rate indicates a situation of survival over time of the event being studied (survival of exports). By defining $n_{i}$ as the number of relationships that remain active in the period $t$ (both complete and censured observations are included) and $h_{i}$ as the number of observations that end exactly in $t$ (number of spells lasting exactly $t$ years), we can estimate the exit rate (hazard) in the following way:

$$
\emptyset(t)=\operatorname{Pr}(T=t \mid T \geq t)=\frac{\operatorname{Pr}(T=t)}{\operatorname{Pr}(T \geq t)}=\frac{h_{i}}{n_{i}}
$$

And based on that, the survival function is determined by:

$$
S(t)=\prod_{t(i) \leq t} 1-\emptyset(t)=\prod_{t(i) \leq t}\left(1-\frac{h_{i}}{n_{i}}\right)
$$

The statistical analysis of the survival functions at product-market level reveals the higher probability of survival of the export flows of P\&C compared to final goods (Graph 2).

\section{Graph 2. Kaplan-Meier Estimates of Survival Functions}

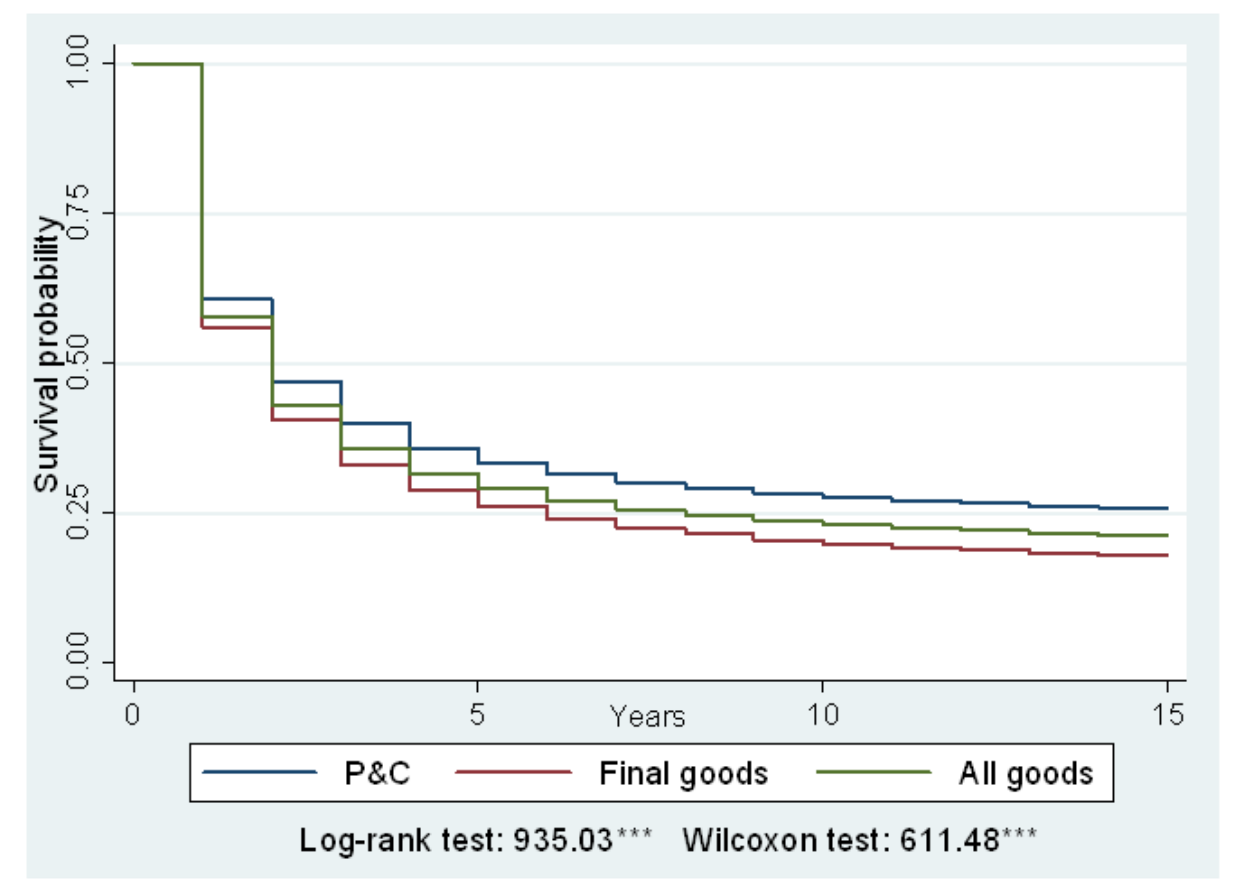

Source: Own elaborations based on UN-COMTRADE data.

The negative and decreasing slope of survival functions shows that the probability of interruption is greater in the first few years, but the risk of failure gradually declines as relationships are longer lasting. Despite the high mortality, the survival rate of $\mathrm{P} \& \mathrm{C}$ exports 
beyond the first year of life rises to $61 \%$, while is just $56 \%$ for final goods. Only $27 \%$ of P\&C flows lasted longer than one decade, a figure which dropped to just $18 \%$ for end products.

\section{Empirical model: Determinants of duration.}

The few studies that examine the duration of trade uphold its persistence based on the existence of sunk entry costs in exporting activity. If companies require previous specific investments to access foreign markets, which are essentially sunk costs, even though the favourable conditions (either internal to the company itself or external) that fostered the decision to begin to export change, it is highly probable that the firms that already export (and that already incurred these costs) will not immediately abandon the exporting activity, showing hysteresis in export behaviour (Baldwin and Krugman, 1989, Impullitti et al., 2011). The importance of sunk costs for exporting companies was also revealed in Roberts and Tybout (1997) and Bernard and Jensen (2004). However, this interpretation does not correspond to the most recent empirical evidence on the short duration of trade flows.

Based on Rauch and Watson's search model (2003), Besedes (2008) showed that when the high degree of uncertainty involved in the start of a trade flow is considered, the low survival rate in their first few years is compatible with a trade model based on the existence of unrecoverable search costs. Uncertainty about the feasibility of trade relationships comes from the exporter's inability to know in advance: first, the precise costs it must incur; second, whether the profitability of the transaction will be sufficient to cover these costs (Albornoz et al., 2010); and third, whether the partner chosen will be able to fulfil the requirements in terms of deadlines, qualities, technical requirements and other production demands. Only after the trade transaction has gotten underway are the adequacy and the appropriateness of the chosen partner revealed, which explains the significant percentage of trade relationships that fail at the beginning. Thus, even though the search costs play a major role in explaining the survival of trade, trust and reliability between partners are also important.

According to the above, high sunk entry costs and any other factor that provides trust and reliability on partner's competence will raise the survival potential of the trade relationships.

This theoretical framework is particularly appropriate for studying the determinants of the duration of trade ties in GPN. The international fragmentation of the value chain requires that each of the productive segments shows a high degree of adaptation to the needs of the production process, especially in technological and product differentiation characteristics ${ }^{4}$, which necessitate close collaboration among network partners. This intense cooperation leads them to share technological knowledge, workforce qualifications and business strategies, creating ties between exporters and importers that foster the stability of the network. What is more, in the majority of cases this cooperation is expressed in investments, which can never be recovered if the relationship fails. The risk of an inadequate choice raises the search costs compared to other organisational forms. So, specifically in differentiated goods trade, search costs are very important; a prediction of the Rauch model (1999) which has been confirmed

\footnotetext{
${ }^{4}$ For example, $\mathrm{P} \& \mathrm{C}$ systems in the automotive industry tend to be specific for each vehicle model (Sturgeon $e t$ al., 2009).
} 
by the empirical evidence. Thus, the trust that each link in the value chain will be capable of properly meeting the production requirements becomes a key factor in production networks, making it more difficult to choose trade partners. Once the aptitude of a new partner has been proven, the trade relationships will be particularly stable in order to avoid new search processes.

But even the production of more standardised $\mathrm{P} \& \mathrm{C}$, where the search costs are lower given the larger supply, requires strict compliance with timeframes, qualities and production requirements for the network to work properly, without interrupting the international production sharing. These specialized suppliers, which often offer intermediate products to different industries (such as electronic chips), have sound knowledge of the market and the product characteristics, and not only do they benefit from the advantages of specialisation but they also take advantage of economies of scale that result from large volumes. Here, the factor that determines their survival in the networks is the trust they generate, based on both their prominent positions in the market and their degree of productive efficiency.

Based on these arguments, we pose two objectives for the empirical model. First, we want to prove that sunk entry costs and uncertainty are indeed particularly important for trade linked to GPN, implying more stability compared to the trade in final goods, a result noted by the descriptive analysis in the previous section.

Secondly, we analyse the different variables that determine the stability of production networks, which we break down into two main groups for purely explanatory purposes, since both are interrelated. The first group includes specific variables of the analyses of duration which try to deal with the degree of uncertainty in the search process and the need for trust and reliability between trade partners. The second group is made up of variables suggested by the theoretical literature on the international fragmentation of production, which stresses the special importance of the trade costs for cross-border production sharing. Table A.3 in the statistical appendix offers a summary of the variables used.

1. Specific variables in duration analyses of trade.

1.1. Initial export value in each transaction. This variable finds theoretical support in the studies of Impullitti et al. (2011) and Rauch and Watson (2003). The former note that the firms that start exporting with large quantities will react to negative shocks by lowering the export volume while remaining in the foreign markets due to the hysteresis effect caused by the sunk entry costs and uncertainty. Rauch and Watson (2003) argue that in a context of uncertainty about the success of a supplier-buyer relationship, a high value in the initial transaction would express trust in the feasibility of the trade tie which lowers the likelihood of failure. As noted previously, since global production sharing requires a particularly high degree of cooperation and trust among the different partners, we would expect a positive impact of this variable on the duration of $\mathrm{P} \& \mathrm{C}$ trade flows. The results yielded by Obashi (2010a), with a lower hazard rate the higher the volume of initial trade, point in this direction.

1.2. The duration of the previous spell, which tries to capture the experience in the exporting activity. Even if they have failed, past attempts make it possible to gather 
knowledge on the export operations of specific products in each target market. Since export costs are largely linked to the difficulties in obtaining relevant information, the capacity acquired in previous experiences will lower the uncertainty and costs of launching new trade relationships. Therefore, we would expect that the longer the preceding period of exporting, the greater the expertise in the trade activity and the lower the likelihood of failing.

1.3. The total volume of exports of a given product, which is included in many analyses of the duration of trade to capture the experience exporting a specific product. In the present study, this variable also carries an additional meaning. According to the theoretical developments in the field of international fragmentation of production (Jones and Kierzkowsky, 1990), this strategy will be efficient for high production volumes in each of the segmented phases, when the economies of scale and the advantages of specialisation offset the costs of a fragmented and dispersed production process. Thus, high volumes of $\mathrm{P} \& \mathrm{C}$ exports offer guarantees of the trade partner's capacity endorsed by both their experience exporting the product and the suppliers' high degree of efficiency. Therefore, we can expect that they are associated with greater success in trade relationships in terms of their continuity.

1.4. The degree of diversification, which provides indication as to the professionalism of the exporter. Geographic diversification (measured by the number of export markets) summarises the exporting experience of a given product which can be sold in highly different markets. It also offers signals as to the solvency of the country in the production and export of a good (country brand/product brand), which lowers mistrust in its capacity to meet the buyer's specific requirements. The diversification of products, measured through the range of goods sold in a specific foreign market, requires an intense knowledge of that market, which eases the exporters' adaptation to the preferences and needs of the buyers and lowers the risk of failure in the trade relationship. ${ }^{5}$ Previous studies, without distinguishing between $\mathrm{P} \& \mathrm{C}$ and final goods, found a positive impact of diversification on the duration of trade flows (Brenton et al., 2010; Nitsch, 2009; Hess and Persson, 2011a).

For the specific case of trade in $\mathrm{P} \& \mathrm{C}$, the number of destination markets and products exported would be one way of measuring the degree of connectivity within the network, that is, the density of ties established inside the network. We would expect that the more extensive the trade ties of $\mathrm{P} \& \mathrm{C}$, that is, the greater their connectivity within the GPN, the more stable their participation in the network will be. We should also bear in mind that geographic and product diversification is characteristic of specialised suppliers with a high productive capacity which provide P\&C with greater efficiency in different markets. ${ }^{6}$ This relationship between

\footnotetext{
${ }^{5}$ Baldwin and Venables (2011) point to the existence of economies of scope in the fragmentation and location abroad of segments of the manufacturing process; the more that the $\mathrm{P} \& \mathrm{C}$ items are relocated abroad, the coordination and communication costs (and risks) which are incurred to monitor these dispersed production blocks rise less than proportionally.

${ }^{6}$ The trade models based on business heterogeneity show how the most productive firms are the ones which may incur the sunk costs involved in exporting. As noted by Volpe and Carballo (2009), geographic and product diversification can be interpreted as the extension of this result to multiple countries and products. If high
} 
diversification and the stability of exports is supported by Chaney (2011). This author develops a model to explain the extensive trade margin based on social networks analysis. He argues that the potential exporters found their contacts in foreign markets in two ways: directly, by seeking the right trade partners abroad, and indirectly, through the contacts that these trade partners already had. The result is a network of contacts that lowers the initial information costs for entering a new market and facilitates the likelihood of getting additional contacts and having geographically dispersed exports. ${ }^{7}$ Even though the paper does not formally introduce the trade in intermediate goods, it does note that the structure of the network is precisely what characterises the trade relationships between importers and exporters of intermediate goods within GPN. Therefore, we can interpret that the countries involved in production sharing systems have greater ease at accessing new export markets and geographically diversifying their sales abroad, while also fostering the stability of those trade flows.

\section{Variables related to international fragmentation of production.}

2.1. Standard variables of the gravity equation: size of the export market (proxied by the importer's $\mathrm{GDP}^{8}$ ), distance between trade partners, and common border and language. We expect a positive impact for the economy size variable (the larger the export market the easier it will be to find potential buyers) and for the common border and language variables (both circumstances would lower the costs of trade and facilitate the stability of exports) and a negative impact for the distance variable. ${ }^{9}$

2.2. Variable for indicating membership in a regional integration area, in our case, the European Union. We expect that the exports targeted at this zone will be particularly stable since trade costs are substantially lower within the regions belonging to these agreements ${ }^{10}$. What is more, we would expect intra-zone trade to be more secure or less subject to the risk entailed in uncertainty about economic policy, legal framework or fluctuations in exchange rates (Zeddies, 2011).

\footnotetext{
productivity is required to export a product (to a market), only the most productive companies will be able to shoulder the costs involved in geographic (product) diversification.

${ }^{7}$ Rauch (2001) also stresses how the social networks lower the search costs for trade partners.

${ }^{8}$ One alternative is to introduce the production value of Machinery and Transport Material instead of the importer's GDP that is a proxy for the import capacity of the destination country. By focusing on a group of sectors and on trade in $\mathrm{P} \& \mathrm{C}$, it might be better to use this alternative variable since the demand for $\mathrm{P} \& \mathrm{C}$ would be in line with the size of these industries in which these P\&C will be used in production. However, the lack of data on production broken down by industry in different countries, mainly in developing countries, and for the most recent years, has led us to use the GDP, despite its limitations.

${ }^{9}$ Gamberoni et al. (2010) argue that given that one major cost associated with distance is time, and that fulfilment of delivery deadlines of the components is necessary for the production sharing system to operate properly, it can be expected that the trade in intermediate goods is particularly sensitive to the impact of distance. The results of their estimates corroborate this. According to these authors, the rising importance of trade linked to production networks could help to explain the so-called distance puzzle, that is, the fact that distance still remains a factor that negatively affects bilateral trade despite the drop in trade costs.

${ }^{10}$ The proliferation of regional integration agreements seems to have stimulated the fragmentation of production and shifted their geography, in a way such that the production networks show a clear regional bias (Baldwin and Venables, 2011; Orefice and Rocha, 2011).
} 
2.3. Variable to capture the impact of the differences in the degree of development (proxied by absolute differences in per capita GDP). The costs of coordinating and managing fragmented production located abroad, as well as the cost of learning the laws and regulations of these foreign countries, can be particularly high in developing countries. What is more, this kind of country tends to lack good transport and communication infrastructures that are essential to ensure the feasibility of the GPN. This would explain why networks tend to be established among countries with an intermediate level of development. In consequence, we expect that excessive differences in the countries' level of development would raise the risk of failure of trade relationships.

2.4. Quality of the institutional framework. The studies by Nunn (2007) and Gamberoni et al. (2010) uphold a positive impact of institutional quality on the value of the trade in intermediate goods. The higher the contractual guarantees offered by the institutional framework, the lower the chance that the supplier of specific inputs will incur investments lower than those required by the final producers. That is, a legal framework that operates properly discourages non-compliance with contracts. Following these arguments, we would expect that production sharing would occur precisely with countries that offer these institutional guarantees. Thus, we expect a positive impact of the quality of the institutional environment (which guarantees compliance with the technical, quality and deadline requirements established in the contract between manufacturing partners) on the stability of the trade flows ${ }^{11}$. We proxy the quality of the institutional environment by the "Rule of Law Index" from the World Bank's Worldwide Governance Indicators; this variable specifically captures the confidence in compliance with contracts and property rights (Kaufmann et al., 2010).

2.5. Finally, we control for the competitive circumstances by including the impact of fluctuations in the real exchange rate. We expect that an overvalued (undervalued) currency can lower (raise) the competitiveness of the exports and harm (or favour) their duration. Hess and Persson (2011a) found that a real depreciation in the currency of the exporting country boosts the likelihood of maintaining the exporting status; in turn, Fugazza and Molina (2010) found that this impact is practically nonexistent, while Obashi (2010a) found that its positive impact on duration is only significant for final goods, not for $\mathrm{P} \& \mathrm{C}$.

\section{Model Specification and Econometric Results.}

Duration models allow us measuring the impact of determinant factors on the probability of persistence in a specific event from a dynamic point of view (Van der Berg, 2001). Therefore, this empirical methodology is especially suitable for the purpose of this paper. The main concept of duration models is not the unconditional probability of a given spell duration (e.g. the probability of maintaining a trade flow exactly five years) but the conditional probability

\footnotetext{
${ }^{11}$ Besedes and Blide (2010) and Fugazza and Molina (2011) prove its impact on the duration of exports with no distinction between $\mathrm{P} \& \mathrm{C}$ and final goods.
} 
(e.g. the probability of leaving a given trade flow in the sixth year conditioned to persistence during the previous five years) (Kiefer, 1988). This conditional probability is the dependent variable and it is known as "hazard rate"( see equation 1).

Cox proportional Hazard models have been heavily deployed in the analysis of trade duration (Besedes and Prusa, 2006b; Nitsch, 2009; Besedes and Blyde, 2010; Obashi, 2010a). This model is based on the assumption that the variables that influence survival have a proportional impact on the baseline hazard function, that is, that their effect is the same throughout the entire period. The main advantage of Cox's model is that it does not require the researcher to adopt any specification on this baseline function (semi-parametric model).

However, the estimates of continuous-time models such as Cox's can be inappropriate for studies of trade duration for several reasons ${ }^{12}$. First, even though we assume that we know the exact moment when the event takes place (interruption of the trade flow), it is recorded in specific time-discrete intervals (annual trade data); this, coupled with the high number of short-lived trade relationships, could result in a considerable number of tied survival times. Secondly, the duration of trade flows with extensive databases (high number of products and countries) is very difficult to properly control for the existence of unobservable heterogeneity (frailty) which would lead to biased estimators and spurious negative duration dependence.

Consequently, the use of time-discrete duration models is more appropriate. Specifically, we suggest a complementary log-log or "clog-log" model which it is the discrete analog of Cox's proportional hazard model (Prentice and Gloeckler, 1978; Jenkins, 2005). To control for unobservable heterogeneity, we include product-country random effects. To capture the duration dependence, we introduce the spell length in logarithms as explanatory variable. ${ }^{13}$ This entails the assumption that the hazard rate varies exponentially with time: the longer the duration spell, the lower the hazard rate.

The results of the econometric estimates can be found in Table 1. The coefficients are presented in exponential form to express the ratio in which the dependent variable (likelihood of failure) changes as the explanatory variable goes up one unit (hazard ratio): values below (above) the unit indicate negative (positive) impact of the explanatory variable on the hazard rate. The impact will be much larger the further the coefficient is from the unit value. As all the explanatory variables are expressed in natural logarithm but Rule of Law and dummy variables, the comparison of coefficients on continuous variables with different scales is possible.

The first three columns show the results using Cox's model, while the next three report the time-discrete models with frailty. The estimate of the rho parameter (fraction of the error variation due to variation in the unobservable individual effects) enables us to appreciate the relative importance of the unobservable heterogeneity in our model. The likelihood-ratio test rejects the null hypothesis of no existence of unobservable heterogeneity. Thus, a timediscrete model is more appropriate in order to control for this heterogeneity.

\footnotetext{
${ }^{12}$ Brenton et al. (2010), Hess and Persson (2011a; 2011b), Fugazza and Molina (2011).

${ }^{13}$ This assumption of duration dependence is similar to the one made when estimating a continuous-time duration model under a Weibull distribution.
} 
In each of the models, in the first specification (columns 1 and 4) we assume that the baseline hazard is common to $\mathrm{P} \& \mathrm{C}$ and final goods and a dummy variable has been introduced to capture the different behaviour of the two types of goods in terms of export survival. The coefficient is statistically significant and above unity, revealing that the hazard rates are substantially higher for final goods than for $\mathrm{P} \& \mathrm{C}$.

Table 1. Estimation Results

\begin{tabular}{|c|c|c|c|c|c|c|}
\hline & \multicolumn{3}{|c|}{ Cox Model } & \multicolumn{3}{|c|}{ Clog-log Model } \\
\hline & Column 1 & Column 2 & Column 3 & Column 4 & Column 5 & Column 6 \\
\hline VARIABLES & All & PyC & Final & All & PyC & Final \\
\hline \multirow[t]{2}{*}{ Initial value } & $0.974^{* * *}$ & $0.966^{* * *}$ & $0.977^{* * *}$ & $0.854^{* * *}$ & $0.810^{* * *}$ & $0.878 * * *$ \\
\hline & $(0.0006)$ & $(0.0011)$ & $(0.0008)$ & $(0.0022)$ & $(0.0039)$ & $(0.0027)$ \\
\hline \multirow[t]{2}{*}{ Duration previous spell } & $0.956 * * *$ & $0.962 * * *$ & $0.952 * * *$ & $0.971^{* * *}$ & $0.979 * * *$ & $0.966 * * *$ \\
\hline & $(0.0025)$ & $(0.0040)$ & $(0.0032)$ & $(0.0028)$ & $(0.0046)$ & $(0.0036)$ \\
\hline \multirow[t]{2}{*}{ Total product exports } & $0.989 * * *$ & $0.985^{* * *}$ & $0.990 * * *$ & $0.993 * *$ & $0.979 * * *$ & 1.000 \\
\hline & $(0.0009)$ & $(0.0014)$ & $(0.0012)$ & $(0.0030)$ & $(0.0048)$ & $(0.0039)$ \\
\hline \multirow[t]{2}{*}{ Number of markets } & $0.859 * * *$ & $0.858^{* * *}$ & $0.861^{* * *}$ & $0.420 * * *$ & $0.395^{* * *}$ & $0.436 * * *$ \\
\hline & $(0.0018)$ & $(0.0031)$ & $(0.0022)$ & $(0.0051)$ & $(0.0084)$ & $(0.0065)$ \\
\hline \multirow[t]{2}{*}{ Number of products } & $0.839 * * *$ & $0.832 * * *$ & $0.829 * * *$ & $0.503^{* * *}$ & $0.528^{* * *}$ & $0.492 * * *$ \\
\hline & $(0.00280)$ & $(0.0046)$ & $(0.0035)$ & $(0.0069)$ & $(0.0124)$ & $(0.0085)$ \\
\hline \multirow[t]{2}{*}{ GDP } & 1.000 & $0.996 * *$ & $1.008^{* * *}$ & $0.948 * * *$ & $0.891 * * *$ & $0.979 * * *$ \\
\hline & $(0.0010)$ & $(0.0017)$ & $(0.0013)$ & $(0.0039)$ & $(0.0066)$ & $(0.0049)$ \\
\hline \multirow[t]{2}{*}{ Common border } & $0.622 * * *$ & $0.538^{* * *}$ & $0.655^{* * *}$ & $0.621^{* * *}$ & $0.592^{* * *}$ & $0.621 * * *$ \\
\hline & $(0.0245)$ & $(0.0413)$ & $(0.0300)$ & $(0.0272)$ & $(0.0512)$ & $(0.0316)$ \\
\hline \multirow[t]{2}{*}{ Common language } & 1.016 & 1.001 & $1.048^{* * *}$ & $0.885^{* * *}$ & $0.760 * * *$ & $0.964 * *$ \\
\hline & $(0.0104)$ & $(0.0167)$ & $(0.0136)$ & $(0.0132)$ & $(0.0191)$ & $(0.0181)$ \\
\hline \multirow[t]{2}{*}{ Distance } & $1.061^{* * *}$ & $1.074^{* * *}$ & $1.043^{* * *}$ & $1.107^{* * *}$ & $1.169 * * *$ & $1.072 * * *$ \\
\hline & $(0.0052)$ & $(0.0085)$ & $(0.0066)$ & $(0.0074)$ & $(0.0130)$ & $(0.0091)$ \\
\hline \multirow[t]{2}{*}{ EU Membership } & $0.951 * * *$ & $0.934 * * *$ & $0.964 * * *$ & $0.756 * * *$ & $0.703^{* * *}$ & $0.786 * * *$ \\
\hline & $(0.0033)$ & $(0.0052)$ & $(0.0044)$ & $(0.0098)$ & $(0.0153)$ & $(0.0127)$ \\
\hline \multirow[t]{2}{*}{ Absolute differences GDPpc } & $1.009 * * *$ & 1.004 & $1.012^{* * *}$ & $1.059 * * *$ & $1.053^{* * *}$ & $1.063 * * *$ \\
\hline & $(0.0020)$ & $(0.00328)$ & $(0.0026)$ & $(0.0067)$ & $(0.0110)$ & $(0.0086)$ \\
\hline \multirow[t]{2}{*}{ Rule of Law } & $1.000^{* * *}$ & $1.000 * * *$ & $1.000 * * *$ & $0.998 * * *$ & $0.995^{* * *}$ & $0.999 * * *$ \\
\hline & $(0.0000)$ & $(0.0000)$ & $(0.0000)$ & $(0.0002)$ & $(0.0005)$ & $(0.0003)$ \\
\hline \multirow[t]{2}{*}{ Variation real exchange rate } & 0.999 & 0.999 & 0.999 & $1.000 * * *$ & $1.000 * *$ & $1.000 * * *$ \\
\hline & $(0.0000)$ & $(0.0000)$ & $(0.0000)$ & $(0.0000)$ & $(0.0000)$ & $(0.0000)$ \\
\hline \multirow[t]{2}{*}{ Final goods } & $1.243^{* * *}$ & & & $1.356 * * *$ & & \\
\hline & $(0.0086)$ & & & $(0.0118)$ & & \\
\hline \multirow[t]{2}{*}{ Duration spell } & \multirow{2}{*}{-} & \multirow{2}{*}{ - } & \multirow[b]{2}{*}{-} & $0.531^{* * *}$ & $0.532 * * *$ & $0.539 * * *$ \\
\hline & & & & $(0.0066)$ & $(0.0106)$ & $(0.0088)$ \\
\hline Observations & 466204 & 212981 & 253223 & 466204 & 212981 & 253223 \\
\hline Spells & 127790 & 51378 & 76412 & 127790 & 51378 & 76412 \\
\hline Log likelihood & -1019946 & -358035 & -601197 & -172997 & -69511 & -103075 \\
\hline Rho & & & & 0.1239 & 0.1535 & 0.1095 \\
\hline (P-value) & & & & $(0.000)$ & $(0.000)$ & $(0.000)$ \\
\hline
\end{tabular}

Notes: Coefficients are expressed as hazard ratio. Standard errors in brackets. *,** and *** indicate significance at $10 \%, 5 \%$ and $1 \%$, respectively. All the variables, except dummies and Rule of Law, are expressed in logarithms. All models include time dummies. The clog-log model includes random effects on the exporterproduct level. 
In the second and third specification of each model (column 2, 3, 5 and 6), both the baseline hazard and the effect of the explanatory variables can be dissimilar for each product group considered. In order to check whether those differences in the covariates are significant, a test of differences was performed which contrasts the null hypothesis that both coefficients are equal. The hypothesis is rejected for most of the explanatory variables, except for the existence of a common border and differences in the real exchange rate (Table A.4).

Focussing on the time-discrete models with frailty, all the variables show the expected impact. The coefficients of those included to capture the uncertainty in the search process confirm that previous export experience diminishes the probability of an export spell dies. So, the higher the initial value of the trade flow and the longer the previous spell, the lower the hazard of failure. Moreover, the greater the total export value and the more product and geographical diversification, the bigger the likelihood of survival. Although for the majority of these variables, the impact is stronger for $\mathrm{P} \& \mathrm{C}$ trade than for final goods, the differential effect is more pronounced in two of them: initial export value and the number of destinations markets. These results support our hypothesis that sunk entry costs and need for trust and reliability are particularly relevant for stability in GPN.

We want to stress that even though both the number of markets and the number of products are factors which lower the hazard rate, the impact is clearly higher for the former. A greater degree of geographic connectivity within the network encourages the stability of participation in it. This result is in line with Volpe and Carballo (2009); using firm-level data, they found that expanding the number of markets to which a given product is exported has a greater stabilising effect on exports than expanding the number of products that are exported to a given market. They therefore argue that the sunk fixed costs which a company must incur when new target markets are incorporated are higher than when new products are added to the export activity. Following their arguments, our results would point out that this differential between the sunk costs of expanding export markets or expanding exported products is higher for P\&C than for final goods.

The coefficients obtained for standard variables in gravity models (distance, common border and language) and for membership in the same regional integration zone confirm their statistically significant impact on the survival of trade in P\&C. Geographic and linguistic proximity and lower trade barriers among the EU members facilitate the stability of exports, mainly those linked to production sharing systems in which the contact between the producerpartners should be closer and more constant over time. What is more, wide economic divergences between countries (examined through absolute differences in per capita income among trade partners) boost the likelihood of exports being interrupted, so that trade relationships between partners with similar levels of economic development are more stable. However, this effect is not greater for $\mathrm{P} \& \mathrm{C}$, which is unquestionably related to the importance of intra-industry trade in final goods. Our results also highlight a positive, albeit minor, impact of institutional quality on the survival rate. ${ }^{14}$ However, the scant difference between

\footnotetext{
${ }^{14}$ Other institutional quality variables used have been the times required to import and export, to execute a contract, to launch a business (only available since the mid-2000's in the World Bank's Doing Business Indicators). These variables are highly correlated with each other and with the Rule of Law variable, which renders it inadvisable to use them in tandem. The same holds true with the quality of infrastructures (motorways,
} 
the coefficients obtained for P\&C and final goods does not allow us to claim, as we expected, that ensuring quality institutions is a particularly important requirement for the stability of participation in international production networks.

Finally, variables such as economy size have a positive effect on the survival of exports, which is once again greater for $\mathrm{P} \& \mathrm{C}$, while the impact of the differences in the real exchange rate is practically nonexistent.

We perform alternative estimates as robustness checks (Table 2). First, we introduce other indicators to measure the degree of geographic and product diversification. The fact that exports are targeted at a large number of countries does not prevent them from concentrating in just a few. For this reason, we introduce the Herfindhal index as an alternative indicator of diversification (Volpe and Carballo, 2009). We expect that concentration by markets and products would harm stability. The results, shown in the first two columns, support the negative impact of concentration on the survival of exports, which once again is higher for the concentration by markets than by products and more intense for $\mathrm{P} \& \mathrm{C}$ than for final goods. That is, geographic diversification is an extremely important variable in guaranteeing the survival in GPN and is more effective than product diversification.

Secondly, we re-estimated the model by incorporating country dummy variables (columns 3 and 4). The coefficients of the explanatory variables were barely altered, and in any event they kept their sign and significance. The only exception is the economy size variable that becomes positive; a larger trading partner does not foster the stability of trade relations. In theory, given that the GDP is a variable that changes over time, its effect can be estimated at the same time as the country's dummy variables. However, these dummy variables will also capture the effect of the trading partner's economy size, which is constant over time. Once this and other effects of the country are controlled, we could argue that rises in the partner's GDP may encourage new export transactions, which bearing in mind the high risk rates in the first few years leads to a rise in the likelihood of interruption. ${ }^{15}$ Thirdly, we exclude from the sample the left-censured observations, that is, those trade flows that already existed at the beginning of the period analysed whose starting year we do not know. We thus re-estimate the model only bearing in mind the new country-product export flows (columns 5 and 6). The results are very similar to the ones obtained when all the spells are taken into account.

Fourthly and finally, we perform the estimates using a probit model with frailty in order to relax the proportional hazard assumption ${ }^{16}$. The conclusions obtained in terms of the positive

railways, ports, airports and information technologies, proxied by the World Bank's Logistics Performance Index: Quality of Trade and Transport-related Infrastructure); a variable particularly important for trade associated with GPN since a delay in the delivery of just a single component could prompt an interruption in the production sharing system (Harrigan and Venables, 2006). These other alternative variables were introduced as analyses of robustness with no considerable changes in the results.

${ }^{15}$ Fugazza and Molina (2011) offer similar reasons to explain an unexpected positive effect of the GDP of the exporting country over the risk rate.

${ }^{16}$ Hess and Persson $(2011 \mathrm{a} ; 2011 \mathrm{~b})$ uphold that the probit is more appropriate for estimating duration model for three reasons: it does not assume proportional hazard; it controls properly for unobservable heterogeneity; and it is a discrete-time model. Brenton et al. (2010) argue that one possible reason why the proportional hazard hypothesis is not sustained is the existence of unobservable heterogeneity, so they suggest estimating a clog-log model to control for this heterogeneity. 
or negative impact on the hazard rate and the differential impact of the variables for $\mathrm{P} \& \mathrm{C}$ and final goods are not altered (Table A.5).

Table 2. Estimation Results: Robustness Analysis.

\begin{tabular}{|c|c|c|c|c|c|c|}
\hline & \multicolumn{6}{|c|}{ Clog-log Model } \\
\hline & \multicolumn{4}{|c|}{ All spells } & \multicolumn{2}{|c|}{$\begin{array}{c}\text { Spells starting in } 1997 \\
\text { (new exporters) }\end{array}$} \\
\hline & Column 1 & Column 2 & Column 3 & Column 4 & Column 5 & Column 6 \\
\hline VARIABLES & $P \& C$ & Final goods & $P \& C$ & Final goods & $\mathrm{PyC}$ & Final goods \\
\hline \multirow[t]{2}{*}{ Initial value } & $0.841 * * *$ & $0.924 * * *$ & $0.861^{* * *}$ & $0.946 * * *$ & $0.925 * * *$ & $0.984 * * *$ \\
\hline & $(0.0033)$ & $(0.0022)$ & $(0.0033)$ & $(0.0023)$ & $(0.0038)$ & $(0.0027)$ \\
\hline \multirow[t]{2}{*}{ Duration previous spell } & $0.963^{* * *}$ & $0.945^{* * *}$ & $0.959 * * *$ & $0.946 * * *$ & $0.915^{* * *}$ & $0.898 * * *$ \\
\hline & $(0.0042)$ & $(0.0032)$ & $(0.0042)$ & $(0.0033)$ & $(0.0043)$ & $(0.0035)$ \\
\hline \multirow[t]{2}{*}{ Total product exports } & $0.842 * * *$ & $0.858^{* * *}$ & $0.818^{* * *}$ & $0.830 * * *$ & $0.880 * * *$ & $0.880 * * *$ \\
\hline & $(0.0032)$ & $(0.0023)$ & $(0.0034)$ & $(0.0024)$ & $(0.0036)$ & $(0.0031)$ \\
\hline \multirow[t]{2}{*}{ Market concentration } & $3.551^{* * *}$ & $2.355^{* * *}$ & $4.230^{* * *}$ & $2.845^{* * *}$ & $2.564 * * *$ & $1.807 * * *$ \\
\hline & $(0.1350)$ & $(0.0626)$ & $(0.1670)$ & $(0.0770)$ & $(0.1070)$ & $(0.0567)$ \\
\hline \multirow[t]{2}{*}{ Product concentration } & $1.636 * * *$ & $1.464 * * *$ & $1.376^{* * *}$ & $1.171^{* * *}$ & $1.352 * * *$ & $1.379 * * *$ \\
\hline & $(0.0947)$ & $(0.0580)$ & $(0.0983)$ & $(0.0548)$ & $(0.0883)$ & $(0.0602)$ \\
\hline \multirow[t]{2}{*}{ GDP } & $0.827 * * *$ & $0.885 * * *$ & $1.111^{* * *}$ & $1.075 * * *$ & $0.871 * * *$ & $0.907 * * *$ \\
\hline & $(0.0042)$ & $(0.0031)$ & $(0.0363)$ & $(0.0269)$ & $(0.0050)$ & $(0.0038)$ \\
\hline \multirow[t]{2}{*}{ Common border } & $0.762^{* * *}$ & $0.736 * * *$ & & & 0.948 & $0.898^{*}$ \\
\hline & $(0.0598)$ & $(0.0343)$ & & & $(0.0909)$ & $(0.0521)$ \\
\hline \multirow[t]{2}{*}{ Common language } & $0.626 * * *$ & $0.716^{* * *}$ & & & $0.801^{* * *}$ & $0.835^{* * *}$ \\
\hline & $(0.0121)$ & $(0.0100)$ & & & $(0.0169)$ & $(0.0137)$ \\
\hline \multirow[t]{2}{*}{ Distance } & $1.235^{* * *}$ & $1.198 * * *$ & & & $1.178 * * *$ & $1.167 * * *$ \\
\hline & $(0.0110)$ & $(0.0077)$ & & & $(0.0120)$ & $(0.0093)$ \\
\hline \multirow[t]{2}{*}{ EU Membership } & $0.705^{* * *}$ & $0.770 * * *$ & $0.859 * * *$ & $0.935^{* *}$ & $0.780 * * *$ & $0.859 * * *$ \\
\hline & $(0.0136)$ & $(0.0111)$ & $(0.0285)$ & $(0.0244)$ & $(0.0167)$ & $(0.0140)$ \\
\hline \multirow[t]{2}{*}{ Absolute differences GDPpc } & $1.050 * * *$ & $1.073^{* * *}$ & $1.307^{* * *}$ & $1.237^{* * *}$ & 1006 & $1.015^{*}$ \\
\hline & $(0.0097)$ & $(0.0078)$ & $(0.0280)$ & $(0.0200)$ & $(0.0104)$ & $(0.0082)$ \\
\hline \multirow[t]{2}{*}{ Rule of Law } & $0.992^{* * *}$ & $0.994 * * *$ & $0.993^{* * *}$ & $0.993 * * *$ & $0.995^{* * *}$ & $0.997 * * *$ \\
\hline & $(0.0003)$ & $(0.0002)$ & $(0.0012)$ & $(0.0009)$ & $(0.0003)$ & $(0.0003)$ \\
\hline \multirow[t]{2}{*}{ Variation real exchange rate } & 1.000 & 1.000 & 1.000 & 1.000 & 1.000 & 1.001 \\
\hline & $(0.0000)$ & $(0.0000)$ & $(0.0000)$ & $(0.0000)$ & $(0.0000)$ & $(0.0000)$ \\
\hline \multirow[t]{2}{*}{ Duration spell } & $0.406 * * *$ & $0.399 * * *$ & $0.412^{* * *}$ & $0.414 * * *$ & $0.422 * * *$ & $0.451 * * *$ \\
\hline & $(0.0055)$ & $(0.0027)$ & $(0.0056)$ & $(0.0029)$ & $(0.00940)$ & $(0.0092)$ \\
\hline Country fixed effects & - & - & Yes & Yes & - & - \\
\hline Observacions & 212981 & 253223 & 212981 & 253223 & 108778 & 151264 \\
\hline Spells & 51378 & 76412 & 51378 & 76412 & 39816 & 62815 \\
\hline Log likelihood & -70887 & -106321 & -69813 & -104625 & -52548 & -80375 \\
\hline Rho & 0.0191 & 0.0000 & 0.0167 & 0.0000 & 0.0251 & 0.0329 \\
\hline (P-value) & $(0.000)$ & $(0.442)$ & $(0.000)$ & $(0.487)$ & $(0.044)$ & $(0.004)$ \\
\hline
\end{tabular}

Notes: Coefficients are expressed as hazard ratio. Standard errors in brackets. *** and *** indicate significance at $10 \%, 5 \%$ and $1 \%$, respectively. All the variables, except dummies and Rule of Law, are expressed in logarithms. All models include time dummies and random effects on the exporter-product level. 


\section{Final Considerations.}

In this paper, we have examined survival capacity in trade relationships focussing on flows associated with cross-border production networks. We have used data on exports of $\mathrm{P} \& \mathrm{C}$ at the product-market level to analyse their survival rates and to delimit the factors that ensure the stability of global production sharing systems. This question takes on particular prominence in a context of economic crisis in the advanced countries as well as to rising competition from the emerging economies.

Our contribution in this work is two-fold. Firstly, we have extended the empirical evidence available, which until now was only available for East Asian countries. We note the greater survival rates of trade in $\mathrm{P} \& \mathrm{C}$ compared to final goods, highlighting the stability of trade linked to GPN.

Secondly, based on theoretical models of production fragmentation and of behaviour of exporting firms, we have proposed a large set of variables to determine the factors than impact on the survival of trade relationships associated with GPN. Using time-discrete survival models which control for the existence of unobservable heterogeneity, we have found that variables such as the initial value of trade, geographic and product diversification, institutional quality, geographic, linguistic and economic proximity and belonging to the same trade integration area are key factors to foster stability in cross-border production sharing systems. These results endorse the hypothesis that the presence of sunk entry costs and the requirements for trust and reliability among trade partners in GPN tend to dissuade radical alterations in the network configuration.

Our estimates emphasize the role of geographic diversification as a stability factor in production networks. This result suggests that the likelihood of remaining within the network depends on how firms are participating in it. That is, exporters of $\mathrm{P} \& \mathrm{C}$ supplying an extensive group of geographically dispersed manufacturers will have a larger probability of remaining in GPN than those operating in a few specific markets. That is, the more extensive the integration in cross-border productions sharing, the more stable the participation.

The delimitation of the conditions for the survival and stability of international networks is an important outcome of our research. It helps to provide information for guiding industrial policy, particularly in middle-income countries which experience a higher risk of being displaced from GPN by emerging economies with lower labour costs. This would be the case of Spain. Its access to the EU in the eighties proved to be a major stimulus to the development of production fragmentation strategies in Europe (Baldwin and Venables, 2011). And even after the recent enlargements to Eastern countries, Spanish integration in European networks shows a high stability. 
Acknowledgement: Financial support from the Castilla-La Mancha Regional Ministry of Education and Science under the project PPII10-0154-9251 (co-financed by FEDER funds) is gratefully acknowledged.

\section{References}

Albornoz, F., Calvo-Pardo, H., Corcos, G. and Ornelas, E., 2010. "Sequential Exporting", CEPR Discussion Papers $n^{\circ} 8103$ (forthcoming in Journal of International Economics).

Baldwin, R. and Krugman, P., 1989. "Persistent Trade Effects of Large Exchange Rate Shocks," Quarterly Journal of Economics, 104, 635-654.

Baldwin, R. and Venables, A., 2011. "Relocating de value chain: off-shoring and agglomeration in the global economy", Discussion Paper no. 544, University of Oxford.

Bernard, A.B. and Jensen, J.B., 2004. "Why Some Firms Export", Review of Economics and Statistics, 86 (2), 561-569.

Besedes, T., 2008. "A Search Cost Perspective on Formation and Duration of Trade", Review of International Economics, 16 (5), 835-849.

Besedes, T. and Blyde, J., 2010. "What drives Export Survival? An analysis of export duration in Latin America", mimeo, Inter-American Development Bank.

Besedes T. and Prusa, T.J., 2006a): "In, Outs, and the duration of trade", Canadian Journal of Economics, 39(1), 266-294.

Besedes T. and Prusa, T.J., 2006b. "Product differentiation and duration of U.S. import trade", Journal of International Economics, 70, 339-358.

Besedes T. and Prusa T.J., 2011. "The Role of Extensive and Intensive Margins and Export Growth", Journal of Development Economics, 96(2), 371-379.

Blázquez, L., Díaz-Mora, C. and Gandoy, R., 2012. "EU Integration and Production networks: Evidence from Spain", Revista de Economía Aplicada (forthcoming).

Brenton, P., Saborowski, Ch. and von Uexkull, E., 2010. "What Explains the Low Survival Rate of Developing Country Export Flows?" The World Bank Economic Review, 24 (3), 474-499.

Chaney, T., 2011. "The network structure of international trade", NBER Working Paper $\mathrm{n}^{\circ}$ 16753.

Fugazza, M. and Molina, A.C., 2011. "On the determinants of exports survival", FREIT Working Paper $\mathrm{n}^{\mathrm{o}} 311$.

Gamberoni, E., Lanz, R. and Piermartini, R., 2010. "Timeliness and Contract Enforceability in Intermediate Goods Trade “, Policy Research Working Paper Series n 5482, World Bank.

Harrigan, J. and Venables, A.J., 2006. "Timeliness and agglomeration", Journal of Urban Economics, 59, 300-316.

Hess, W. and Persson, M., 2011a. "Exploring the Duration of EU Imports", Review of World Economics, 147(4), 665-692.

Hess, W. and Persson, M., 2011b. "The Duration of Trade Revisited. Continuous-Time vs. Discrete-Time Hazards", Empirical Economics (forthcoming).

Impullitti, G., Irarrazabal, A. and Opromolla, L., 2011. "A theory of entry into and exit from export markets", mimeo, available in https://files.nyu.edu/ldo202/public/hyst2.pdf.

Jenkins, S., 2005. Survival analysis (Lecture Notes, Draft Book). Available in: http://www.iser.essex.ac.uk/teaching/degree/stephenj/ec968/

Jones, R.W. and Kierzkowski, H., 1990. "The Role of Services in Production and International Trade: A Theoretical Framework", in Jones, R. and Krueger, A. (Eds.), 
The Political Economy of International Trade, Basil Blackwell, Oxford.

Kaplan, M.L. and Meier, P., 1958. "Nonparametric Estimation from Incomplete Observations", Journal of the American Statistical Association, 53, 457-481.

Kaufmann, D., Kraay, A. and Mastruzzi, M., 2010. "The Worldwide Governance Indicators: Methodology and Analytical Issues", Policy Research Working Paper no. 5430, World Bank.

Kiefer, N., 1988. "Economic Duration Data and Hazard Functions", Journal of Economic Literature, 26(2), 646-679.

Kimura, F. and Obashi, A., 2010. "International Production Networks in Machinery Industries: Structure and Its Evolution", ERIA Discussion Paper Series no 2010-09.

Nitsch, V., 2009. "Die Another Day: Duration in German Import Trade", Review of World Economics, 145(1), 133-154.

Nunn, N., 2007. "Relationship-Specificity, Incomplete Contracts and the Pattern of Trade," The Quarterly Journal of Economics, 122(2), 569-600.

Obashi, A., 2010a. "Stability of production Networks in East Asia: Duration and survival of trade", Japan and the World Economy, 22, 21-30.

Obashi, A., 2010b. "Stability of International Production Networks: Is East Asia Special?", International Journal of Business and Development Studies, 2 (1), 63-94

Orefice, G. and Rocha, N., 2011. "Deep Integration and Production Networks: an Empirical Analysis", WTO Working Paper no. 2011-11.

Prentice, R.L. and Gloeckler, L.A., 1978. "Regression analysis of grouped survival data with application to breast cancer data", Biometrics, 34, 57-67.

Rauch, J.E., 1999. "Networks versus Markets in International Trade," Journal of International Economics, 48, 7-35.

Rauch, J.E., 2001. "Social and Business Networks in International Trade", Journal of Economic Literature, 39, 1177-1203.

Rauch, J.E. and Watson, J., 2003. "Starting small in an unfamiliar environment," International Journal of Industrial Organization, 21(7), 1021-1042.

Roberts, M.J. and Tybout, J.R., 1997. "The Decision to Export in Columbia: An Empirical Model of Entry with Sunk Costs", American Economic Review, 87 (4), 545-564.

Sturgeon T.J., Memedovic, O., Van Bieserbroeck, J. and Gereffi, G., 2009. "Globalisation of the Automotive Industry: Mean Features and Trends", International Journal of Technological Learning, Innovation and Development, 2 (1/2), 7-24.

Van den Berg, G., 2001. "Duration Models: Specification, Identification and Multiple Durations", Handbook of Econometrics, Vol 5, 3381-3460.

Volpe, C. and Carballo, J., 2009. "Survival of New Exporters: Does it Matter How They Diversify?", Inter-American Development Bank Working Paper no. 140.

Zeddies, G., 2011. "Determinants of International Fragmentation of Production in the European Union", Empirica, 38(4), 511-537. 


\section{Statistical Annex:}

Table A.1. Products included in the sample.

\begin{tabular}{|c|}
\hline HS 1996 classification \\
\hline $\begin{array}{l}\text { P\&C: } 840140,840290,840390,840490,840590,8406,8407,8408,8409,8410,8411,8412,8413,8414, \\
841520,841590,8416,8417,841891,841899,841990,842091,842099,842123,842129,842131,842191, \\
842199,842290,842390,842490,8431,843290,843390,843490,843590,843691,843699,843790,843890, \\
843991,843999,844090,844190,844240,844250,844390,8448,845090,845190,845240,845290,845390, \\
845490,845590,8466,846791,846792,846799,846890,8473,847490,847590,847690,847790,847890, \\
847990,8480,8481,8482,8483,8484,8485,8503,850490,8505,850690,8507,850890,850990,851090, \\
8511,8512,851390,851490,851590,851690,851790,851840,851850,851890,8522,8529,853090,8531, \\
8532,8533,8534,8535,8536,8537,8538,8539,8540,8541,8542,854390,8544,8545,8546,8547,8548, \\
8607,8706,8707,8708,870990,8714,871690,8803,8805,9001,9002,9003,900590,900691,900699, \\
900791,900792,900890,900990,901090,901190,901290,9013,9014,901590,901790,902490,902590, \\
902690,902790,902890,902990,903090,903190,903290,9033,9104,9110,9111,9112,9113,9114,9209 .\end{array}$ \\
\hline
\end{tabular}

Table A.2. Export Partners included in the sample.

\begin{tabular}{|c|c|}
\hline \multirow{2}{*}{ EU-27 } & $\begin{array}{c}\text { UE-14: Austria, Belgium-Luxemburg, Denmark, Finland, France, Germany, Greece, } \\
\text { Ireland, Italy, Netherlands, Portugal, Sweden and United Kingdom. }\end{array}$ \\
\cline { 2 - 3 } Rest of & $\begin{array}{r}\text { New Member States (NMS): Bulgaria, Cyprus, Czech Rep., Estonia, Hungary, } \\
\text { Latvia, Lithuania, Malta, Poland, Rumania, Slovakia and Slovenia. }\end{array}$ \\
\hline World & $\begin{array}{c}\text { Angola, Saudi Arabia, Algeria, Argentina, Australia, Bangladesh, Bolivia, Brazil, } \\
\text { Canada, Chile, China, Colombia, Costa Rica, Cuba, Hong Kong, Croatia, Ecuador, } \\
\text { Egypt, United Arab Emirates, The Philippines, Guatemala, Equatorial Guinea, } \\
\text { Lebanon, India, Indonesia, Iran, Iraq, Israel, Japan, Jordan, Kazakhstan, Kuwait, The } \\
\text { Pakistan, Panama, Peru, Qatar, Rep. Korea, Russia, Senegal, Serbia, Singapore, Syria, } \\
\text { Rep. Dominican, Rep. South African, Sri-Lanka, Switzerland, Thailand, Tunisia, } \\
\text { Turkey, USA, Ukraine, Uruguay, Venezuela and Vietnam. }\end{array}$ \\
\hline
\end{tabular}


Table A.3. Explanatory variables: definition and sources.

\begin{tabular}{|c|c|c|}
\hline Variable & Definition & Source \\
\hline Initial value & $\begin{array}{l}\text { Value of export in the first year of the spell, expressed } \\
\text { in nominal USA dollars. }\end{array}$ & $\begin{array}{l}\text { COMTRADE } \\
\text { (United Nations) }\end{array}$ \\
\hline $\begin{array}{l}\text { Duration } \\
\text { previous spell }\end{array}$ & Number of years that the previous spell lasted & \begin{tabular}{|l} 
COMTRADE \\
(United Nations)
\end{tabular} \\
\hline $\begin{array}{l}\text { Total product } \\
\text { exports }\end{array}$ & $\begin{array}{l}\text { Value of the exports of a given product to all the } \\
\text { partners, expressed in nominal USA dollars. }\end{array}$ & $\begin{array}{l}\text { COMTRADE } \\
\text { (United Nations) }\end{array}$ \\
\hline $\begin{array}{l}\text { Number of } \\
\text { markets }\end{array}$ & $\begin{array}{l}\text { Number of markets to which a given product is } \\
\text { exported }\end{array}$ & $\begin{array}{l}\text { COMTRADE } \\
\text { (United Nations }\end{array}$ \\
\hline $\begin{array}{l}\text { Number of } \\
\text { products }\end{array}$ & Number of products exported to a given market & \begin{tabular}{|l|l|} 
COMTRADE \\
(United Nations
\end{tabular} \\
\hline $\begin{array}{l}\text { Market } \\
\text { concentration }\end{array}$ & $\begin{array}{l}\text { Herfindahl index calculated as the sum of } \\
\text { the squares of export shares of different countries for a } \\
\text { given product. }\end{array}$ & $\begin{array}{l}\text { COMTRADE } \\
\text { (United Nations }\end{array}$ \\
\hline $\begin{array}{l}\text { Product } \\
\text { concentration }\end{array}$ & $\begin{array}{l}\text { Herfindahl index calculated as the sum of the } \\
\text { squares of market shares of all the products exported to } \\
\text { a given market }\end{array}$ & $\begin{array}{l}\text { COMTRADE } \\
\text { (United Nations }\end{array}$ \\
\hline GDP & $\begin{array}{l}\text { Gross Domestic Product, expressed in nominal US } \\
\text { dollars. }\end{array}$ & $\begin{array}{l}\text { World Development } \\
\text { Indicators. The World } \\
\text { Bank. }\end{array}$ \\
\hline Distance & $\begin{array}{l}\text { The Great Circle distance between capital cities of the } \\
\text { trading partners, }\end{array}$ & $\begin{array}{l}\text { CEPII : } \\
\text { http://www.cepii.fr }\end{array}$ \\
\hline $\begin{array}{l}\text { Common } \\
\text { border }\end{array}$ & $\begin{array}{l}\text { Dummy variable, which is unity if trading partners } \\
\text { have a common border and zero otherwise. }\end{array}$ & \\
\hline $\begin{array}{l}\text { Common } \\
\text { language }\end{array}$ & $\begin{array}{l}\text { Dummy variable, which is unity if trading partners } \\
\text { have a common language and zero otherwise. }\end{array}$ & $\begin{array}{l}\text { CEPII : } \\
\text { http://www.cepii.fr } \\
\end{array}$ \\
\hline $\mathbf{E U}$ & $\begin{array}{l}\text { Dummy variable, which is unity if the partner country } \\
\text { belongs to the EU and zero otherwise. }\end{array}$ & \\
\hline $\begin{array}{l}\text { Absolute } \\
\text { differences } \\
\text { GDPpc }\end{array}$ & $\begin{array}{l}\text { Absolute differences in per capita incomes between } \\
\text { trading partners (in nominal US dollars). The } \\
\text { conversion to dollars is done using the Atlas method. }\end{array}$ & $\begin{array}{l}\text { World Development } \\
\text { Indicators. The World } \\
\text { Bank. }\end{array}$ \\
\hline Rule of Law & $\begin{array}{l}\text { Index that captures perceptions of the extent to which } \\
\text { agents have confidence in and abide } \\
\text { by the rules of society, and in particular the quality of } \\
\text { contract enforcement, property rights, the police, } \\
\text { and the courts, as well as the likelihood of crime and } \\
\text { violence. The values range from } 0 \text { to } 100 \text {. }\end{array}$ & $\begin{array}{l}\text { Worldwide } \\
\text { Governance } \\
\text { Indicators. The } \\
\text { World Bank }\end{array}$ \\
\hline $\begin{array}{l}\text { Variation real } \\
\text { exchange rate }\end{array}$ & $\begin{array}{l}\text { Annual change in the log of relative real exchange rate. } \\
\text { Relative real exchange rate is defined as the nominal } \\
\text { exchange rate adjusted by the relative consumer prices } \\
\text { indices. }\end{array}$ & $\begin{array}{l}\text { World Development } \\
\text { Indicators. The World } \\
\text { Bank. }\end{array}$ \\
\hline
\end{tabular}


Table A.4. Test for significant differences in coefficients between P\&C and Final goods

\begin{tabular}{|l|l|l|}
\hline \multirow{2}{*}{} & \multicolumn{2}{|c|}{ Clog-log Model } \\
\cline { 2 - 3 } & Coefficient & P-value \\
\hline P\&C or Final & $-2.414^{* * *}$ & $(0.243)$ \\
\hline Interc. P\&C of Final & $-0.662^{* * *}$ & $(0.0142)$ \\
\hline Interc. Time dummies & $0.0674^{* * *}$ & $(0.0120)$ \\
\hline Common border & $-0.508^{* * *}$ & $(0.0848)$ \\
\hline Interc.Common border & 0.0217 & $(0.0989)$ \\
\hline Commun language & $-0.266^{* * *}$ & $(0.0242)$ \\
\hline Interc. Common language & $0.227^{* * *}$ & $(0.0307)$ \\
\hline Distance & $0.152^{* * *}$ & $(0.0107)$ \\
\hline Interc. Distance & $-0.0809 * * *$ & $(0.0137)$ \\
\hline Duration previous spell & $-0.0210^{* * *}$ & $(0.0047)$ \\
\hline Interc. Prev. Spells & $-0.0141^{* *}$ & $(0.0060)$ \\
\hline Rule of law & $-0.00468^{* * *}$ & $(0.00042)$ \\
\hline Interc. Rule of law & $0.00330^{* * *}$ & $(0.000530)$ \\
\hline Differences in GDPpc & $-0.113^{* * *}$ & $(0.0071)$ \\
\hline Interc. Differences in GDPpc & $0.0912^{* * *}$ & $(0.0087)$ \\
\hline Initial value & $-0.205^{* * *}$ & $(0.0042)$ \\
\hline Interc. Initial value & $0.0724 * * *$ & $(0.0048)$ \\
\hline EU membership & $-0.349 * * *$ & $(0.0213)$ \\
\hline Interc. EU Membership & $0.105^{* * *}$ & $(0.0268)$ \\
\hline Variation real exchange rate & $-1.93 e-06 * *$ & $(0.0000)$ \\
\hline Interc. Var. Diff. Exch. Rate & $2.03 e-07$ & $(1.12 \mathrm{e}-06)$ \\
\hline Market concentration & $-0.902 * * *$ & $(0.0173)$ \\
\hline Interc. Market concentration & $0.0536^{* * *}$ & $(0.0178)$ \\
\hline Product concentration & $-0.618^{* * *}$ & $(0.0214)$ \\
\hline Interc. Product concentration & $-0.105^{* * *}$ & $(0.0253)$ \\
\hline Observations & 466,204 & \\
\hline Number of spell & 127,790 & \\
\hline Rho & 0.126 & $(0.000)$ \\
\hline
\end{tabular}

Notes: To contrast significant differences in coefficients between P\&C and Final goods, we re-estimate a clog$\log$ model with the whole sample (P\&C and final goods) considering both a dummy variable to control the kind of product $(0=\mathrm{P} \& \mathrm{C}, 1=$ final good)and the intercept variables between the dummy and every explanatory variable (interc. Variables). Significant coefficients for the "interc. Variables" indicate significant differences between $\mathrm{P} \& \mathrm{C}$ and final goods. $* * *$ and $* * *$ indicate significance at $10 \%, 5 \%$ and $1 \%$ respectly. All the variables, except dummies and Rule of Law, are expressed in logarithms. 
Table A.5. Estimations Result: comparison of clog-log model and probit model.

\begin{tabular}{|c|c|c|c|c|c|c|c|c|}
\hline \multirow{2}{*}{ VARIABLES } & \multicolumn{4}{|c|}{ Probit } & \multicolumn{4}{|c|}{ Cloglog } \\
\hline & $\mathrm{P} \& \mathrm{C}$ & Final goods & $\mathrm{P} \& \mathrm{C}$ & Final goods & $P \& C$ & Final goods & $\mathrm{P} \& \mathrm{C}$ & Final goods \\
\hline \multirow[t]{2}{*}{ Initial value } & $-0.133^{* * *}$ & $-0.091^{* * *}$ & $-0.120 * * *$ & $-0.059 * * *$ & $-0.210 * * *$ & $-0.130 * * *$ & $-0.173^{* * *}$ & $-0.0792 * * *$ \\
\hline & $(0.0033)$ & $(0.0022)$ & $(0.0031)$ & $(0.0020)$ & $(0.0048)$ & $(0.0031)$ & $(0.0038)$ & $(0.0024)$ \\
\hline \multirow[t]{2}{*}{ Duration previous spell } & $-0.013^{* * *}$ & $-0.022 * * *$ & $-0.027 * * *$ & $-0.042 * * *$ & $-0.021 * * *$ & $-0.035 * * *$ & $-0.037 * * *$ & $-0.057 * * *$ \\
\hline & $(0.0031)$ & $(0.0025)$ & $(0.0031)$ & $(0.0025)$ & $(0.0047)$ & $(0.0037)$ & $(0.0043)$ & $(0.0034)$ \\
\hline \multirow[t]{2}{*}{ Total product exports } & $-0.018 * * *$ & -0.002 & $-0.140 * * *$ & $-0.126 * * *$ & $-0.021 * * *$ & 0.000 & $-0.172 * * *$ & $-0.153^{* * *}$ \\
\hline & $(0.0034)$ & $(0.0029)$ & $(0.0031)$ & $(0.0027)$ & $(0.0049)$ & $(0.0039)$ & $(0.0038)$ & $(0.0027)$ \\
\hline \multirow[t]{2}{*}{ Number of markets } & $-0.729 * * *$ & $-0.685^{* * *}$ & & & $-0.929 * * *$ & $-0.830 * * *$ & & \\
\hline & $(0.0140)$ & $(0.0104)$ & & & $(0.0213)$ & $(0.0148)$ & & \\
\hline \multirow[t]{2}{*}{ Number of products } & $-0.511 * * *$ & $-0.596 * * *$ & & & $-0.638 * * *$ & $-0.708 * * *$ & & \\
\hline & $(0.0165)$ & $(0.0127)$ & & & $(0.0235)$ & $(0.0173)$ & & \\
\hline \multirow[t]{2}{*}{ Market concentration } & & & $1.105^{* * *}$ & $0.777 * * *$ & & & $1.267 * * *$ & $0.856 * * *$ \\
\hline & & & $(0.0306)$ & $(0.0242)$ & & & $(0.0381)$ & $(0.0266)$ \\
\hline \multirow[t]{2}{*}{ Product concentration } & & & $0.421 * * *$ & $0.299 * * *$ & & & $0.492 * * *$ & $0.381 * * *$ \\
\hline & & & $(0.0453)$ & $(0.0330)$ & & & $(0.0579)$ & $(0.0396)$ \\
\hline \multirow[t]{2}{*}{ GDP } & $-0.077 * * *$ & $-0.012 * * *$ & $-0.152 * * *$ & $-0.105 * * *$ & $-0.116 * * *$ & $-0.0208 * * *$ & $-0.190 * * *$ & $-0.122 * * *$ \\
\hline & $(0.0052)$ & $(0.0038)$ & $(0.0041)$ & $(0.0032)$ & $(0.0073)$ & $(0.0051)$ & $(0.0051)$ & $(0.0035)$ \\
\hline \multirow[t]{2}{*}{ Common frontier } & $-0.335^{* * *}$ & $-0.304 * * *$ & $-0.136 * * *$ & $-0.184^{* * *}$ & $-0.524^{* * *}$ & $-0.477^{* * *}$ & $-0.272^{* * *}$ & $-0.306 * * *$ \\
\hline & $(0.0516)$ & $(0.0323)$ & $(0.0475)$ & $(0.0304)$ & $(0.0865)$ & $(0.0509)$ & $(0.0785)$ & $(0.0467)$ \\
\hline \multirow[t]{2}{*}{ Common language } & $-0.179 * * *$ & -0.014 & $-0.378 * * *$ & $-0.286 * * *$ & $-0.274 * * *$ & $-0.036 * *$ & $-0.469 * * *$ & $-0.334 * * *$ \\
\hline & $(0.0177)$ & $(0.0140)$ & $(0.0154)$ & $(0.0124)$ & $(0.0251)$ & $(0.0187)$ & $(0.0193)$ & $(0.0140)$ \\
\hline \multirow[t]{2}{*}{ Distance } & $0.105^{* * *}$ & $0.046^{* * *}$ & $0.169 * * *$ & $0.154^{* * *}$ & $0.156^{* * *}$ & $0.069 * * *$ & $0.211^{* * *}$ & $0.180 * * *$ \\
\hline & $(0.0077)$ & $(0.0063)$ & $(0.0070)$ & $(0.0057)$ & $(0.0111)$ & $(0.0084)$ & $(0.0089)$ & $(0.0064)$ \\
\hline \multirow[t]{2}{*}{ EU Membership } & $-0.223^{* * *}$ & \begin{tabular}{|l|}
$-0.156 * * *$ \\
\end{tabular} & $-0.230 * * *$ & $-0.181 * * *$ & $-0.353^{* * *}$ & $-0.241 * * *$ & $-0.349 * * *$ & $-0.261 * * *$ \\
\hline & $(0.0142)$ & $(0.0113)$ & $(0.0137)$ & $(0.0109)$ & $(0.0218)$ & $(0.0162)$ & $(0.0193)$ & $(0.0144)$ \\
\hline \multirow[t]{2}{*}{ Absolute differences GDPpc } & $0.036^{* * *}$ & $0.049 * * *$ & $0.037^{* * *}$ & $0.060 * * *$ & $0.052^{* * *}$ & $0.061^{* * *}$ & $0.049 * * *$ & $0.071 * * *$ \\
\hline & $(0.0072)$ & $(0.0058)$ & $(0.0069)$ & $(0.0057)$ & $(0.0104)$ & $(0.0081)$ & $(0.0092)$ & $(0.0072)$ \\
\hline \multirow[t]{2}{*}{ Rule of Law } & $-0.004 * * *$ & $-0.001 * * *$ & $-0.007 * * *$ & $-0.005^{* * *}$ & $-0.005^{* * *}$ & $-0.001 * * *$ & $-0.008 * * *$ & $-0.005 * * *$ \\
\hline & $(0.0003)$ & $(0.000234)$ & $(0.0003)$ & $(0.0002)$ & $(0.0004)$ & $(0.0003)$ & $(0.0003)$ & $(0.0002)$ \\
\hline \multirow[t]{2}{*}{ Variation real exchange rate } & $0.000^{*}$ & $0.000^{* *}$ & $0.000 * *$ & 0.000 & 0.000 & $0.000 * * *$ & 0.000 & 0.000 \\
\hline & $(0.0000)$ & $(0.0000)$ & $(0.0000)$ & $(0.0000)$ & $(0.0000)$ & $(0.0000)$ & $(0.0000)$ & $(0.0000)$ \\
\hline \multirow[t]{2}{*}{ Duration spell } & $-0.377 * * *$ & $-0.373 * * *$ & $-0.493 * * *$ & $-0.522 * * *$ & $-0.630 * * *$ & $-0.618 * * *$ & $-0.900 * * *$ & $-0.918 * * *$ \\
\hline & $(0.0116)$ & $(0.0105)$ & $(0.0109)$ & $(0.0108)$ & $(0.0199)$ & $(0.0164)$ & $(0.0137)$ & $(0.00677)$ \\
\hline \begin{tabular}{|l|} 
Observations \\
\end{tabular} & 212981 & 253223 & 212981 & 253223 & 212981 & 253223 & 212981 & 253223 \\
\hline Spells & 51378 & 76412 & 51378 & 76412 & 51378 & 76412 & 51378 & 76412 \\
\hline Log likelihood & -68761 & -102118 & -70493 & -106008 & -69511 & -103075 & -70887 & -106321 \\
\hline Rho & 0.1131 & 0.0976 & 0.0931 & 0.0866 & 0.1535 & 0.1095 & 0.0191 & 0.0000 \\
\hline (P-value) & $(0.000)$ & $(0.000)$ & $(0.000)$ & $(0.000)$ & $(0.000)$ & $(0.000)$ & $(0.000)$ & $(0.442)$ \\
\hline
\end{tabular}

Notes: Standard errors in brackets. *, ** and *** indicate significance at $10 \%, 5 \%$ and $1 \%$, respectively. All the variables, except dummies and Rule of Law, are expressed in logarithms. All models include time dummies and random effects on the exporter-product level. 